\title{
Facility Management in Ghanaian Public Second Cycle Institutions and Implications for Effective School Facility Management. A Study of the Upper West Region
}

\author{
Charles Amoyea Atogenzoya $^{1 *} \quad$ Joseph Kidodo $^{2}$ \\ 1.Department of Building Technology and Estate Management, Wa Polytechnic, PO box 553, Wa, Ghana \\ 2.Department of Land Economy, College of Arts and Built Environment, KNUST, PMB KNUST, Kumasi, \\ Ghana
}

\begin{abstract}
Education is a very invaluable part of every nation's development agenda and a catalyst for building a better and more sustainable future for all. To this end, successive governments in Ghana through the GETFund continue to undertake substantial investment in facilities in public second cycle institutions as part of wider efforts to deliver quality education. Proper management of these facilities thus becomes imperative if their intended purposes are to be fully realized. Purposive sampling techniques were employed to select headmasters and teachers in charge of facility management from twenty-seven (27) public second cycle institutions in the Upper West Region for interviews. This study examined the current system of facilities management in the institutions studied to establish whether they were capable of ensuring effective school facility management. The study found out that the institutions had no designated departments in charge of the management of their respective school facilities and also lacked well-defined structures for effective school facilities management. It was also revealed that the utilities masters or madams who manage school facilities in public second cycle institutions have no estate or facility management background. The results of the study further established that effective facility management in public second cycle institutions is hampered by lack of technical knowledge of maintenance issues by those in charge of managing the facilities, poor financial base to support maintenance, low participation by community members in managing school facilities, and lack of operational guidelines on facility management in the second cycle institutions. The study recommends that estate offices be created and manned by qualified staff be set up in second cycle institutions. In addition, an operational policy manual should be developed to guide the management of facilities in second cycle institutions across Ghana.
\end{abstract}

Keywords: Education, School Facilities, Facilities Management, Public Second Cycle Institutions.

DOI: $10.7176 / \mathrm{JEP} / 11-7-08$

Publication date:March $31^{\text {st }} 2020$

\section{Introduction}

Education is a very invaluable part of every nation's development agenda. It's not only very necessary for growth and development, but for sustainable development. Education plays a vital role in the economic or social development process of society. With the industrilisation of economies and urbanization, the importance of education has gained increased recognition because nations' requirement for sophisticated citizens will continue to increase (Peaslee, 1969). According to Oyesiku (2002), nations, regions and the world would be severely limited in development without education, which is a key factor for physical and economic growth. Recognizing the role of education as a catalyst for building a better and more sustainable future for all, the United Nations (in December, 2002) declared the "United Nations Decade of Education for Sustainable Development (2005-2014)" (UN, 2002). This commitment gained further strength when Member States pledged to promote Education for Sustainable Development beyond the end of the Decade at the 2012 United Nations Conference on Sustainable Development - Rio+20 (UN, 2012). Recognizing the importance of education, successive governments of Ghana have sought to use education as the vehicle for accelerating the implementation of their development policies and programmes. Notable among such policies are the Free Compulsory Universal Basic Education introduced in 1992 and the Free Senior High School policy currently being implemented by the NPP government led by President Nana AkuffoAddo.

Education however does not occur in a vacuum. This therefore brings to the fore the critical issue of school facilities. It is the legal and moral responsibility of each nation to ensure that every child has access to quality education, albeit in most third-world countries the posture of government officials often seem to suggest that this responsibility is only moral in nature. In many states in the USA, for instance, the courts have determined that the ability of school facilities to meet a standard of educational adequacy (that is to provide an educational setting that allows the state's determined curriculum to be taught) is a significant part of this responsibility (BEST, 2005). Physical infrastructure with specific reference to buildings should therefore constitute a greater proportion of a country's investment in education (BEST, 2005). It is in this light that, Ghana has established the Ghana Education Trust Fund (GETFund) to provide funding to supplement government effort for the provision of educational 
infrastructure as well as the promotion of staff development and research within the public sector from the pretertiary to the tertiary level.

In order to attain the quality education that every child is entitled to, great attention needs to be given to not only the provision but also the quality of school facilities. This is because there is empirical evidence that shows a direct relationship exists between the quality of school facilities and the quality of the products of the school (Asiabaka, 2008). High quality, high-performing, well-designed and maintained school facilities have been found to have a direct and indirect impact on the teaching and learning process (BEST, 2005). Facilities, especially buildings, therefore, need to be properly catered for. It is important that improvements on lands are kept in good physical condition in other to perform the required functions of providing a sound environment for all. This is vital because as noted by Asiabaka (2008) the physical environment of a school is a major determining factor in the attainment of its objectives. Facilities management in schools, especially Second Cycle Institutions, should therefore be an integral part or component of the conditions for learning. The management of such school facilities should provide a sense of ownership, security, and safety (Lackney \& Picus, 2008) and should last a lifetime. Administrators therefore need to establish and monitor facility management programs for their schools.

A review of the literature shows that some research has been done on school facility management. The focus however has been on issues such as school facilities disability (eg Tudzi and Ansah, 2008), the relationship between the condition of school facilities (school's physical environment) and academic quality (see Asiabaka, 2008; Paya and Rubin (2006; Tanner, 2000; Yarbrough 2001), investment in school facility and end-user satisfaction (eg Adjei-Twum et al, 2012) etc. Not much is known on the capacity of public second cycle institutions in Ghana to ensure effective management of school facilities. Appreciation of public second cycle institutions' facility management structures, issues of competences and the problems of facility management is thus imperative. The core objective of this paper is to examine the facility management structures in public second cycle institutions in Ghana and ascertain the capacity of the system to deliver effective management of facilities.

\section{Literature Review}

The term "facility management" has as many meanings as there are many disciplines in the social sciences. As an evolving concept different people and organisations have different views about facility management and so it has been described in several ways without a firm consensus. According to the British Institute of Facilities Management (BIFM), facilities management is the integration of multi-disciplinary activities within the built environment and the management of their impact on people and the workplace (BIFM, 2016). The International Facilities Management Association (2016), on its part, defines facilities management as a profession that encompasses multiple disciplines to ensure functionality of the built environment by integrating people, place, process and technology. Pathirage, Amaratunga and Baldry (2008), have also defined, facilities management as an integrated approach to operating, maintaining, improving and adapting the buildings and infrastructure of an organisation in order to create an environment that strongly supports the primary objectives of that organisation.

Whatever the definition of facilities management may be (in terms of nature and scope), three things are common in the variant views on its definition. These are work environment, people and organisational goals. The various definitions suggest that Facilities Management provides a supporting management function to the core business of an organization, which concentrates on the area of interface between physical workplace and people; and requires a multi-skill approach to integrate people, place, process and technology in executing its support functions. The function could be as complex as strategic planning to as menial as cleaning services and a range of services in between. From the foregoing, this paper aligns with the view that facilities management is the management of an organization's work environment and everything associated with the organisation (such as people and processes) with the aim of achieving the organization's strategic objective. The environment of an organisation refers to the elements relevant to its operation (Stoner, Freeman and Gilbert, 1996) and they include both direct and indirect elements.

The term "school facilities" refers to all types of buildings (for academic and non-academic activities), equipment (for academic and non-academic purposes), school grounds, the various facilities (toilets, lighting, acoustics, storage, parking lots, etc.) within the school grounds and inside the buildings, and support services (Asiabaka, 2008). The school facility also includes furnishing, materials and supplies, equipment and information technology, as well as various aspects of the building grounds such as athletics fields, playgrounds, areas of outdoor learning, and vehicular access and parking. To perform its function of aiding teaching and learning, an effective school facility must be responsive to the changing programs of educational delivery, and at a minimum should provide a physical environment that is comfortable, safe, secure, readily accessible, well illuminated, well cleaned, well ventilated, and aesthetically pleasing according to best standards and practice. The school facility is much more than a passive container of the educational system (Tanner, 2008). School facilities management therefore is the application of scientific methods in the planning, organizing, decision-making, coordinating and controlling of the physical environment for learning for the actualization of educational goals and objectives (Asiabaka, 2008). 
School facilities management is indispensable because various studies have found a link between the condition of school facilities (physical environment) and educational quality or students' outcomes (e.g., Earthman and Lemastes, 1998; Lemasters, 1997; Paya and Rubin, 2006; Tanner, 2000; Wohlwil van Vliet, 1985; Yarbrough 2001). There is a general belief that the condition of schools' learning environment (including infrastructure) has an important impact on teachers' effectiveness and students' performance in academics and non-academic related areas like sports. In a study conducted by Paya and Rubin (2006), it was revealed that although aspects of the poor quality of school infrastructure were present in both high-and low-performing schools, it was noticed that all the low-performing schools were particularly poorly maintained and neglected (in terms of the state of the classroom buildings, the furniture and the toilets). concluded that the "the physical environment of a college classroom could impact student learning" (Hill and Epps, 2009:16). In emphasizing the significance of school facility condition to quality assurance in schools, Ayeni and Adelabu (2002) also noted that the better a school's facilities, the better it can meet its goals that include equipping students with desirable skills, knowledge, and attitudes that enable them to work and live in the society of knowledge. Ayeni and Adelabu concluded that the quality of infrastructure and learning environment has a strong influence on academic standard, which is an index of quality assurance in a school. Earthman (2002) opined that comfortable classroom temperature and smaller classes enhance teachers' effectiveness and provide opportunities for students to receive more individual attention, ask more questions, participate more fully in discussions, reduce discipline problems and perform better than students in schools with sub-standard buildings by several percentage points. Durosaro (1998), on school plant planning and the administrative effectiveness of principals in secondary schools in Oyo (Nigeria), reported that well planned and maintained schools had higher student retention and were more effective than others. Durosaro further noted that if the education curriculum is sound and well operated while the school facilities are in disrepair and badly managed the result of the teaching and learning activities will be negative. This implies that there is a positive relationship between good school environment and effective teaching and learning activities. A study by Olutola (1989), also found that schools adequately provided with the necessary facilities scored higher in their rate of utilization of infrastructural facilities and performance in West African School Certificate Examination subjects. The findings of these studies clearly establish there is a positive relationship between good school environment and effective teaching and learning activities.

The physical attributes of the educational setting do not only affect academic performance but have been found to also affect students' attitude and behavior (Cash 1993; Hines, 1996; and Lanham, 1999). Maxwell (2009) found that the physical attributes of school facilities play an important role in students' academic performance, attitudes, and behavior. Well-designed and maintained facilities (effective facilities management) send a powerful message to students about the importance authorities place on education (Maxwell, 2009).

Better educational attainment and outcomes are achieved when the school environment is well maintained. Yet various studies have indicated that public schools' infrastructure suffers from deplorable conditions (Stevenson, 2009; Gilbred, 2007; Bello and Loftness, 2010). Not only that, but public schools' facilities have been found to deteriorate at a faster rate than they can be repaired, and faster than most public facilities (Lunenburg and Qrnstein, 2008). In the light of the aforementioned research findings, the importance of effective facility management in public second cycle institutions cannot therefore be underestimated. This study contributes to expanding the frontier of knowledge on facility management in educational institutions by focusing on second cycle institutions in the Upper West Region of Ghana.

\section{Methodology}

To be able to effectively examine the issue of Facility Management in public Second Cycle Institutions, the study adopted both quantitative and qualitative methodologies. This is because, as pointed out by Rudestam and Newton (2001:45), quantitative and qualitative approaches combine the rigor and precision of experimental designs and quantitative data with the depth of understanding provided by qualitative methods and data. The quantitative component of the study was necessary to understand and present the issues relating to statistics about the key aspects of facility management in the selected schools. However, because quantitative data would not provide enough space for participants' perspectives to be explored in greater detail, the study also relied greatly on qualitative data and analysis so as to be able to present the respective and varied views and opinions of the persons involved in the management of school facilities. The collection and analysis of both quantitative and qualitative data was necessary for a broad appreciation of the facility management issues in second cycle institutions in the Upper West Region of Ghana.

The study adopted a purposive sampling (Kumar, Stern, and Anderson, 1993) technique to select twenty-seven public second cycle institutions in eight districts. All twenty-seven (27) schools that were selected were those that were government-owned and thus qualified for the setting of this study which is "public second cycle institutions". This resulted in twenty-seven heads of institutions and twenty-seven senior housemasters or mistresses (also known as 'utilities masters/mistresses'). Snowball (Mills and Huberman, 1994) sampling was employed in selecting 27 opinion leaders and 1 Ghana Education Service official. 
Data was gathered from both primary and secondary sources. Primary data was collected using questionnaires and in-dept interviews. The goal of structured interviewing (questionnaires) was to ensure that interviewees' responses could be aggregated to determine a pattern. This was also to achieve some reliability in the responses. According to Bryman and Bell (2007), this can be achieved under structured interview where respondents are made to answer exactly the same questions read out in the same order as they are printed on the interview schedule. In-depth interviews were audio-taped, transcribed within 24 hours, and subjected to coding and analysis. We triangulated interview data with non-participant observations and secondary data (from a variety of sources such as records of the selected schools, GES policy documents, practitioner articles, etc.) through multiple rounds of comparison and validation (Mills and Huberman, 1994) in order to ensure the validity of the statements and data obtained (Denzin and Lincoln, 2005).

The quantitative data was analyzed using SPSS software after it was edited and imputed into the system. Descriptive statistics such as percentages and charts were generated for patterns of issues presented in this report. Qualitative data, obtained through in-dept interviews transcribed from audio recordings and notes, was manually coded and written under selected themes which were then used to support the quantitative data in section 4 below.

\section{Results and discussions}

\subsection{Sex Composition of respondents}

All the respondents were senior housemasters or mistresses (also known as utility masters or madams) of the twenty-seven public second cycle institutions covered under the study. Out of the twenty-seven respondents interviewed, 20 (representing 74.1\%) were males (senior housemasters) whilst 7 (representing 25.9\%) were females (senior housemistresses). The males were dominating as far as the position of senior housemastership is concerned in the study area as evidenced by the study results. This reflects the general situation in Ghana where most leadership positions are dominated by men.

\subsection{Existence of Facility Management Units}

The study sought to find out if the institutions have any designated units in charge of facility management. It was revealed that all twenty-seven (27) public second cycle institutions (representing 100\%) had no designated departments for facility management. Management of school facilities is handled by whoever is the senior housemaster or mistress of the time and supervised by the school's Assistant headmaster, headmistress (in charge of domestic affairs). With increasing facility number and sophistication (due to technological advancement) it has become best practice for institutions to introduce facility management units or estate management units handle by facility management experts. Though not common with government and quasi-government institutions, reference can be made to public universities, public hospitals, the Volta River Authority, the Electricity Company Ghana, and Ghana Water Company Limited which have all established Facility or Estate Management units spearheading their assets management to support their core businesses. This is not the case with the public second cycle institutions. All aspects of facility management were found to be handled by the senior housemasters and mistresses who are supervised by the Assistant headmasters or mistresses (in charge of domestic affairs).

\subsection{Facility Management Structures in Public Second Cycle Institutions}

As part of efforts to determine the effectiveness of facility management in public second cycle institutions, the study sought to examine the various structures put in place to ensure effective management of school facilities. It revealed the following:

4.3.1 Qualification Requirements

It was revealed that there was a qualification requirement that one has to meet in order to become the person responsible for managing facilities in public second cycle institutions. These qualification requirements, however, were purely the ones that needed to be met before one can become a senior housemaster or mistress in line with Ghana Education Service (GES) regulations and do not have any link to facility management. From the survey conducted, it was revealed that persons qualified to be senior housemasters or mistresses are those with superintendent grades. And according to GES regulations, for one to qualify for a superintendent grade, the fellow must be a trained teacher with a diploma or a degree in any field of related study, must serve continuously for a period of at least four years with GES, and must be licensed under the Ghana's teacher union (GES, 1987). There is no requirement for one to have estate or facility management knowledge, skills or competences in order to manage the facilities. Anybody who attains the rank of superintendent and appointed to the position of senior housemaster or mistress automatically assumes the responsibility of managing the facilities. One utility master had this to say:

I have no qualification in estate or facility management. I was appointed as a senior housemaster and as part of my responsibilities as such, I am in charge of the management of the facilities in the school (Interview, 2019).

This statement was corroborated by one headmaster who explained that: 
...per our [GES] setup right now, you don't need any qualification in estate management before you can become the utilities master or mistress. These [utility masters or mistresses) are teaching staff of the superintendent rank which qualifies them to be appointed as senior housemasters or mistresses. [...] and senior housemasters or mistresses are in charge of school facilities (Interview, 2019

The case with utility masters or mistresses was found to be different from that of other support services such as accounting and catering where professionals such as bursars and matrons were at the realm of affairs. 4.3.2 Performance Measurement

On whether there was a performance measurement system in place for utilities masters or mistresses with respect to facility management, all the twenty-seven (27) schools covered in the survey had none. All the heads (100\%) interviewed were however unanimous in their views that in rare situations utilities masters or mistresses have had to be changed due to overly-poor performance. For instance, one head teacher noted "we have no key performance measurement system in place, but we try to ensure that utilities masters or mistresses deliver. Where one continuously fails to execute his or her duties well as a senior housemaster or mistress, we normally replace them with someone else".

The question that begs for an answer is "what is the measure of overly poor?". It is worthy to note, that in the absence of well-defined guidelines on how performance should be measured, discretion is used to measure the performance of the utilities masters or mistresses. The study also revealed that apart from the issue of discretion and personal sentiments in assessing performance of senior housemasters/mistresses who manage the facilities, some schools have more liberty to change utilities masters/mistresses than others. The more the staff in a school who qualify to be appointed as senior housemasters/mistresses or utilities masters/mistresses, the easier it is to change non-performing utilities masters or mistresses in such institutions.

4.3.3 Responsibility Allowance

In order to assess the level of motivation of senior house masters or mistresses for effective and efficient facility management in public second cycle institutions, the study sought to find out whether utilities masters or madams receive any responsibility allowance for their extra work as school facilities managers. The study revealed that there is no responsibility allowance for utilities masters or madams. This is reflected in the remarks of one senior housemistress:

There is absolutely no allowance for the extra duties of being a senior housemaster or mistress. As a person

of the rank of a superintendent, you are entitled to the salary that all persons within that rank [superintendent grade] are entitled to. As for being a senior house master or mistress with all the additional duties, you don't get any extra duty allowance for it (Interview, 2019).

We probed further to find out the effect of this absence of allowances for utilities masters and mistresses on facility management. The study revealed that the lack of responsibility allowance was found to be impacting negatively on effective facility management as some utilities masters or madams complained about heavy workload (especially in bigger schools) and lack of real motivation for them to do the work. This lack of compensation for utilities masters' or mistresses' extra work efforts has the propensity to lower their morale for the assigned tasks.

4.3.4 Records Management System

An effective records management system is very vital for effective and efficient facility management. This is because the nature of school facilities makes it necessary that the facility manager keeps up-to-date, comprehensive, reliable and accurate records. If the facility manager lacks or fails to use relevant information at a particular time, an important date could be overlooked, or a necessary item of information might not be available at the right time and this could have a disastrous consequence. In view of this, the study sought to assess the records management systems in public second cycle institutions as part of the overall objective of examining the various structures put in place to ensure effective management of school facilities in public second cycle institutions. It was revealed that most (70\%) of the schools surveyed lacked efficient records management systems. An efficient records system for the purpose of facility management includes but not limited to; an asset register, a survey file, terrier, a perpetual diary, management, services and repairs files. Apart from the management, services and repairs files that the institutions tried to keep, all the twenty-seven utilities masters and mistresses interviewed were oblivious of the existence and importance of the asset register, the survey file, the terrier and the perpetual diary within the realm of facility management. This revelation was not surprising as it reaffirmed the reality that senior housemaster or mistresses are not the right people to handle facilities management in public second cycle institutions. After all, senior housemasters or mistresses are trained teachers and not trained facility managers. They are somehow deficient in some technical areas of facilities management and this tends to affect their work output as managers of school facilities.

\subsubsection{Training}

Training was one of the issues considered under facility management structures in public second cycle institutions. Two aspects of training were considered; training before assumption of duty as utilities masters or mistresses and in-service training for facility management staff. The study revealed that the respondents (utilities masters or 
mistresses) had no training at all prior to their assumption of duty as facility managers. One headteacher explained: No training on how to manage facilities is organized for staff prior to their assumption of duty as senior housemasters or mistresses (Interview, 2019).

Also explaining the lack of training, one senior housemistress noted "there is no such thing (training on how to manage facilities) in place for senior housemasters or mistresses, as far as I know. Once you become a senior housemaster or mistress, your responsibility for the management of facilities starts automatically with your assumption of duty as the senior housemaster or mistress". Further engagement with officials at the various district G.E.S offices revealed that no such training is available for senior housemasters or mistresses when they are appointed.

We don't have anything like that in our current setup. It's the school heads who appoint the senior housemasters and mistresses. Our mandate is to ensure that those who are due for promotion to superintendent ranks are duly promoted after they have met the necessary promotion requirements. [...] After that, whoever becomes a senior housemaster or mistress and when becomes an internal issue of the various senior high schools (Interview, 2019).

On the issue of in-service training for facility management staff, the figure below shows that only $26.1 \%$ of respondents have had some form of in-service training of some sort whilst an overwhelming majority (73.9\%) had never had any in-service training of any kind since assumption of responsibility as utilities masters or mistresses. Even with the small number who benefited from some level of in-service training, the training was more of sensitization workshops (focusing on minor issues such as nature or scope of facility management, components or facets of facility management, relevance of facility management to quality education, among others) than capacitybuilding seminars (concentrating on changing trends in school facility management, contemporary facility management strategies and tools, ICT and facility management, etc.).

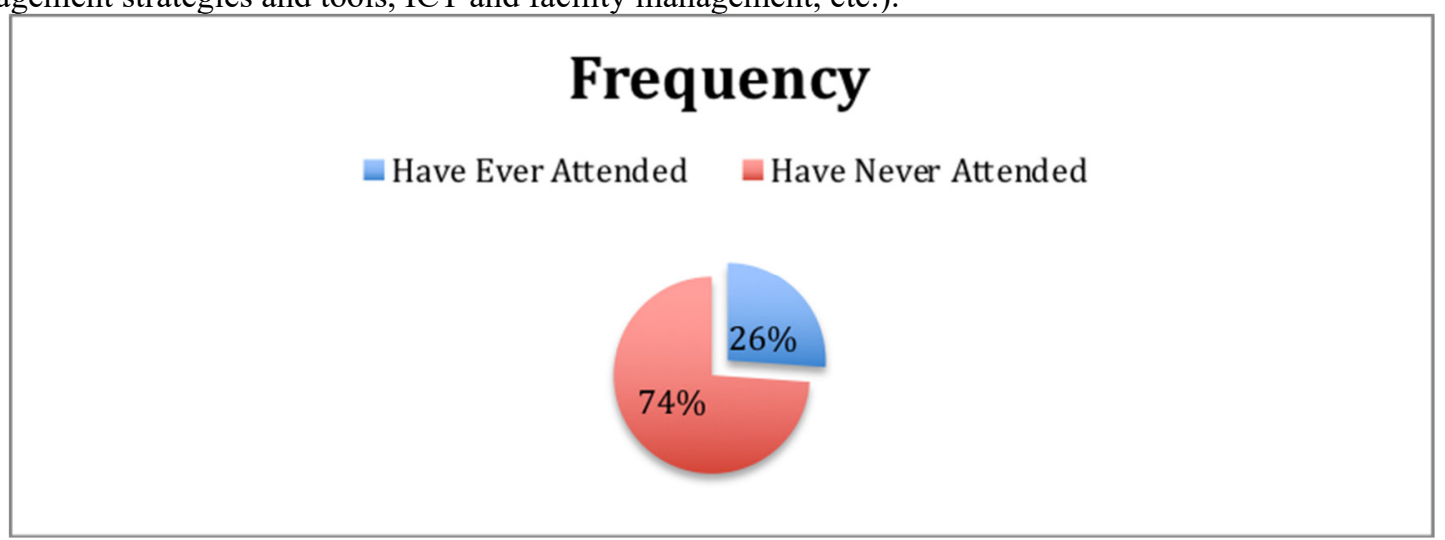

Figure I. In-Service Training for Senior Housemasters/mistresses

Figure 1 shows the percentages for senior housemaster/mistresses who have ever attended an in-service training and those who have never attended an in-service training.

4.3.6 Maintenance Policy

Maintenance is a major component of facility management and as such the importance of a maintenance policy to effective school facility management cannot be underestimated. As a strategy within which maintenance decisions are taken, a maintenance policy is the ground rule for the allocation of resources between the alternative types of maintenance actions (servicing, rectification and replacement) that are available to management. The study however revealed that none of the respondent public second cycle institutions has a maintenance policy. While routine maintenance is key to long-term cost-effective utilization of buildings and the proper operation of building systems (BEST, 2005) and should therefore be encouraged, the study revealed that most of the public second cycle institutions were engaged in deferred maintenance practices. In view of the fact that none of the schools had a maintenance policy, it was not surprising that deferred maintenance (resulting from the postponement of preventative, scheduled, and emergency work) was widely practiced in the schools surveyed. This approach often leads to deterioration of facilities before action is taken. In some of the schools covered some facilities were in deplorable state partly attributable to lack of preventative maintenance plan which could have been structured within a maintenance policy if there were any.

\subsection{Challenges of Facility Management in Public Second Cycle Institutions}

4.4.1 Lack of technical knowledge of maintenance issues

One of the challenges that were found to be associated with facility management in public second cycle institutions is lack of technical knowledge of maintenance issues. Utilities masters or mistresses as well as their supervising officers lack training in facility management and requisite knowledge in maintenance issues. The study found out that preventative maintenance was alien to utilities masters and mistresses $(100 \%$ of the respondents had no idea 
about preventative maintenance) as the only form of maintenance practice they seem to understand was corrective maintenance (repairs). With an already weak financial base to support maintenance work, the effect of this is obvious. Once a facility defect occurs, further delays are made in getting funds to carry out repair works, and this often leads to facilities falling into states of disrepair. An understanding of maintenance issues is expected to guide a facility manager with regards to what maintenance policy should be in place and this (maintenance policy) in turn helps the facility manager to come out with a maintenance plan. Without any knowledge in maintenance, it is almost impossible for utilities masters or mistresses to formulate a maintenance policy and subsequently a maintenance plan. The practice of engaging in corrective maintenance is therefore as a result of the lack of maintenance policies and plans as noted elsewhere in this paper.

4.4.2 Poor financial base to support maintenance

Maintenance is a major component of facility management and arguably constitutes the most erratic and recurring outgoing as far as facility management costs are concerned. Unfortunately, a poor financial base to support maintenance was found as one of the challenges of facility management in public second cycle institutions. Major sources of funding for facility maintenance in public second cycle institutions include Internally Generated Funds (IGFs), Government (GES and GETfund), Parent Teachers' Associations (PTAs), Old Students' Associations (OSAs) and other stakeholders. Regarding IGF's, one headmaster contended, these are barely sufficient to cover our maintenance needs. What we generate internally is woefully inadequate to cover our maintenance and other needs. Most of the time we rely on the benevolence of old students and donations from the PTA. (Interview, 2017) Governments over the years have failed to make adequate resources available for proper maintenance of existing facilities but rather direct attention towards the creation of new structures.

4.4.3 Low community participation

Facilities management is a collective responsibility of the state (national government), local government authorities (Metropolitan, Municipal and District Assemblies), staff and students of the individual schools, ParentTeachers Associations, Old Students' Associations (alumini), the community where the school is located and other stakeholders. In recent times, perhaps due to an increased level of understanding about their role in providing quality education, PTA's and OSA's have contributed significantly in the provision and maintenance of school facilities. Unfortunately, in most developing countries like Ghana, that level of consciousness (by most communities) of the fact that school facility management is a shared responsibility between them (the communities), school authorities and government is low. Interviews with some community members and opinion leaders of the various communities (where the institutions are sited) covered for this study revealed they do not only see government to be responsible for management and maintenance of school facilities. They perceive their contribution towards facility management can only be financial in nature. In the words of one opinion leader:

$\mathrm{Ah}$ ! What business do we the community members have with managing school facilities? It is government

who built the school and so it's his responsibility to ensure that facilities in the school are in a good condition.

Our duty is to pay school fees". (Interview, 2017)

Due to poverty, the financial support that community members could offer to support the maintenance of school facilities in their communities, they are unable.

Another opinion leader in Lambussie community opined: "most of us in this community find it difficult to pay our children's school fees not to talk of contributing towards the maintenance of the schools' facilities"

The study revealed that community members were not aware that they could contribute to effective facility management by protecting school facilities against irresponsible use, acts of vandalism and against damage by animals.

4.4.4 Lack of a national minimum adequacy standards policy

Another challenge that was found to be affecting effective facility management in public senior high schools is "lack of a national minimum adequacy standards policy". A very significant proportion of national revenue is devoted to providing quality education through school construction, capital improvements and the provision of support facilities. However, there is no policy in place that sets a benchmark as the minimum adequate standard of facility management required of schools. The lack of such a policy means that public second cycle institutions have no minimum standard of facility management to aspire to thereby making facility management standards in schools discretionary and unstandardized as earlier noted.

\section{Conclusion}

The study sought to examine the current system of facility management in public second cycle institutions and to establish whether it was capable of ensuring effective school facility management in contemporary times in public second cycle institutions. The study found out that public second cycle institutions have no designated departments in charge of the management of their respective school facilities. Management of school facilities was found to be handled by senior housemasters or mistresses and supervised by the school's assistant headmaster or headmistress in charge of domestic affairs. The senior housemasters/mistresses are not only non-facility management professionals but also lack relevant training in facility management. There is no estate officer with expertise in 
facility management who handles all issues relating to facility management in the schools. Secondly, the study also revealed lack of well-defined structures for effective facility management in public second cycle institutions. Under this, it came to light that public second cycle institutions lack efficient records management systems as far as facility management is concerned.

Moreover, it was revealed that there is no responsibility allowance for senior house masters or mistresses who handle the tasks of facility management and maintenance. There are also no defined work assessment criteria in place to evaluate their performance and no maintenance policy to guide maintenance decisions. Additionally, it came to light that the qualification criteria used in selecting utility masters or madams have no link with facility management since there is no provision for the possession of facility or estate management knowledge, skills or competences in the selection criteria.

In determining whether public second cycle institutions have the capacity for effective school facility management, the results of the study showed that public second cycle institutions do not have the capacity for ensuring effective school facility management within broad best-practice principles. This is because, senior housemasters and housemistresses as well as their supervising officers (assistant headmasters/mistresses in charge of domestic affairs, headmasters/mistresses and circuit supervisors) are not trained facility managers by profession. Secondly, no training is giving to utilities masters and madams prior to assumption of duty as facility managers. Lastly, in-service training is woefully inadequate evidenced by the overwhelming majority of utilities masters and madams $(73.7 \%)$ who have never attended any in-service training on facility management. The lack of adequate training is a clear and compelling revelation that utilities masters and madams in particular in public second cycle institutions lack the requisite expertise to effectively manage school facilities. The management of school facilities by utilities masters or madams in public second cycle institutions therefore was found to amount to putting square pegs in round holes.

The results of the study also established some problems that further impair the efforts of public second cycle institutions towards achieving effective facility management. The problems identified included lack of technical knowledge of maintenance issues, poor financial base to support maintenance, low community participation in managing school facilities and lack of a national minimum adequacy standards policy that serves as a guide to public second cycle institutions.

Given the vital role quality school facilities and for that matter effective facility management play in ensuring quality education, the paper recommends the following:

There should be an establishment of estate units in public second cycle institutions. The time has come for serious thought to be given to the idea of recruiting estate/facility managers for public second cycle institutions in Ghana.

There is also the need to have a minimum adequacy standards policy, nation-wide school facility inventory policy and maintenance criteria and evaluation.

Educating and sensitizing communities to develop a sense of ownership of schools located within their areas as a way to strengthen and make management of facilities in the second cycle institutions in Ghana robust and sound is further recommended.

\section{References}

Anti-Twum, A., Tudzi, A., and Kidido, J. (2012). Capital Investment and End-User Satisfaction in Infrastructure Projects in Tertiary Institutions in Ghana: Evidence from Kumasi Polytechnic. In Badu E, Dinye R, Ahazie $\mathrm{D}$, Owusu-Manue D (Eds) Procs 1st International Conference on Infrastructure Development in Africa (ICIDA), March 22-24, 2012, Kumasi, Ghana. Pp300-331.

Asiabaka, I. P. (2008). The Need for Effective Facility Management in Schools in Nigeria. New York: Science Journal 1(2), 10-21.

Atkin, B and Brooks, A. (2000). Total facilities management. Oxford: Blackwell Science Ltd

Ayeni, A.J., \& Adelabu, M.A. (2012). Improving Learning Infrastructure and Environment for Sustainable Quality Assurance Practice in Secondary Schools in Ondo State, South-West, Nigeria. International Journal of Research Studies in Education, 1(1), 61-6

Bryman, A. and Bell, E. (2007). Business Research Methods. Second Edition. New York: Oxford University Press. Bello, M.A. \& Loftness, V. (2010). Addressing Inadequate Investment in School Facility Maintenance. School of Architecture paper 50. Carnegie Mellon University.

BEST, (2005). Recommended Policies for Public School Facilities. [Online] Available http://www.21 csf.org/csfhome/publications/modelpolicies/planningsectionmay2005.pdf (February 25, 2019).

Cash, C. S. (1993). Building Conditions and Student Achievement and Behavior. Doctoral dissertation, Virginia Polytechnic Institute and State University, Blacksburg, VA.

Denzin, N. (1989). The Research Act: A Theoretical Introduction to Sociological Methods (3rd ed.). Englewood Cliffs, NJ: Prentice Hall. 
Durosaro, D. O. (1998). School Plant Management in Nigeria: Trends, Issues and Problems in Management of Nigerian Education - Project Monitoring and School Plant Maintenance. A publication of the National Institute for Planning and Administration, 2, 53-63.

Earthman, G.I. (2002). School Facility Conditions and Student Academic Achievement; UCLA's Institute for Democracy, Education, \& Access (IDEA): Los Angeles, CA.

Earthman, G. I., \& Lemasters, L. (1998). Where Children Learn: A Discussion of How a Facility Affects Learning [Information Analysis]. Blacksburg, VA: Educational Facility Planners Conference.

Financial and Fiscal Commission (2009). Submission on Norms and Standards for School Infrastructure: Financial and Fiscal Commission, Pretoria, South Africa.

Fenker, M. (2004). Organizational Change, Representations and Facilities. In Facilities Management: Innovation and Performance. Alexander, K. (ed.) U.K. Taylor Francis.

GES (1987). Conditions and Scheme of Service and Code of Professional Conduct for Members of the Ghana Education Service (Teaching Personnel). [Online] Available https://searchworks.stanford.edu/view/1838124 (March 1, 2019)

Gibberd (2007), South Africa's School Infrastructure Performance Indicator System. [Online] Available from www.csir.org.za (April 3, 2019).

Hill, M. C., \& Epps, K. K. (2009). Allied Academics International Conference. Proceedings of the Academy of Educational Leadership, 14 (1), 15-19.

Hines, E. W. (1996). Building Conditions and Student Achievement and Behavior. Unpublished doctoral dissertation, Virginia Polytechnic Institute and State University, Blacksburg, VA.

IFMA, (2016), What Is Facility Management? [online] Available https://www.ifma.org/about/what-is-facilitymanagement (July 4, 2019)

Kumar, N., Stern, L. W., \& Anderson J.C. (1993). Conducting Interorganizational Research using Key Informants. Academy of Management Journal, 36, 1633-1651.

Lackney, K \& Picus, S. (2008). The Impact of Schools Facilities on Learning. Texas.

Lanham III, J. W. (1999) Relating Building Conditions and Classroom Conditions to Student Achievement in Virginia's Elementary Schools. Unpublished doctoral dissertation, Virginia Polytechnic Institute and State University, Blacksburg, VA.

Lateef, O.A., Khmidi, M.F., \& Idrus, A. (2010). "Building Maintenance Management In A Malaysian University Campus: A Case Study." Australian Journal of Construction Economics.

Lemasters, L. (1997). A Synthesis of Studies Pertaining to Facilities, Student Achievement, and Student Behavior; Educational Leadership and Policy Studies Center; University of Virginia: Blacksburg, VA

Lunenburg, F. C., \& Ornstein, A. O. (2008). Educational Administration: Concepts and Practices. Belmont, CA: Wadsworth/Cengage Learning.

Maxwell, L.E. (1999). School Building Renovation and Student Performance: One District's Experience.

Miles, M., \& Huberman, A., (1994). Qualitative data analysis: An expanded sourcebook, 2nd edition. Thousand Oaks, CA: Sage.

Olutola, A. D. (1989). Educational Facilities and Students' Performance in West African School Certificate Examination. International Journal of Educational Management, 1(1), 17-24.

O'Neill, D.J., \& Oates, A.D., (2001). The Impact of School Facilities on Student Achievement, Behavior, Attendance, and Teacher Turnover Rate in Central Texas Middle Schools. Educational Facility Planner, 36(3), 144-22.

Ornstein, L., Aleinov, I., \& Rind, D. (2009). A Synthesis of Studies Pertaining to Facilities, Student Achievement, and Student Behavior. Blacksburg, VA: Virginia Polytechnic and State University.

Oyesiku, O.O. (2002). Environment, Physical Planning and Development In Nigeria, College Press And Publishers Ltd, Ibadan Oxford: Blackwell Science Ltd.

Pathirage, C.P., Haigh, R.P., Amaratunga, R.D.G., \& Baldry, D. (2008) Knowledge Management Practices in Facilities Organisations: A Case Study. Journal of Facilities Management, 6(1), 5-22. [online] Available http://usir.salford.ac.uk/10046/ (July 5, 2019)

Peaslee, A.L. (1969). Education's Role in Development. Economic Development and Cultural Change, 17(3), 293318.

Raya, R. \& Rubin, V. (2006). Safety, Growth and Equity: School Facilities. [Online] Available www.policylink.org.za (May 20, 2019).

Stevenson, K. (2006). Model Policies for Preserving Historic Schools. National Trust for Historic Preservation. USA.

Stoner, J.A.F., Freeman, R.E., and Gilbert, D.R. (1996). Management. New Delhi: Prentice Hall

Tanner, C. K. (2000). The Influence of School Architecture on Academic Achievement. Journal of Educational Administration, 38(4), 309-330.

Tanner, C. K. (2006). Effects of The School's Physical Environment on Student Achievement. Educational 
Planning, 15(2), 25-44.

Tanner, C. K. (2008). Explaining Relationships among Student Outcomes and the School's Physical Environment. Journal of Advanced Academics, 19(3), 444-471.

Tudzi, E.P., \& Ansah, S. (2008). Facilities Management: A Missing Fulcrum in the Educational Reform. The Ghana Surveyor, 1(1), 18-20.

Wohlwill, J. F., \& van Vliet, W. (1985). Habitats for Children: The Impacts of Density. Hillsdale, NJ: Lawrence Erlbaum Associates.

UNESCO (2014). World Conference on Education for Sustainable Development. Aichi-Nagoya. 10-12 November 2014 [online] Available http://www.unesco.org/new/en/unesco-world-conference-on-esd-2014/ (July 4, 2019)

UN (2012), United Nations Conference On Sustainable Development, Rio+20. Rio de Janeiro. 20-22 June 2012. [online] Available https://sustainabledevelopment.un.org/rio20 (July 4, 20190

UN (2002). UN Decade of Education for Sustainable Development. [online] Available http://www.desd.org/about.html (July 4, 2019)

Yarborough, K. A. (2001). The Relationship of School Design to Academic Achievement of Elementary School Children. Unpublished Doctoral Dissertation, University of Georgia, Athens.

Yin, R.K., (1989). Case Study Research Design and Methods, Sage: Newbury Park. 